\title{
Inhibition of ABA-induced stomatal closure by fusicoccin is associated with cytosolic acidification-mediated hydrogen peroxide removal
}

\author{
Ai-Xia Huang, Xiao-Ping She, Jin-Liang Zhao and Yun-Ying Zhang
}

\begin{abstract}
Background: Fusicoccin (FC), a fungal phytotoxin produced by Fusicoccum amygdale, causes the inhibition of ABA-induced stomatal closure. The mechanism of inhibition is remaining unclear. We analyzed the role of hydrogen peroxide $\left(\mathrm{H}_{2} \mathrm{O}_{2}\right)$ and relationship between $\mathrm{H}_{2} \mathrm{O}_{2}$ removal and cytosolic $\mathrm{pH}$ changes during inhibition of ABA-induced stomatal closure by FC.

Results: According to the results, $\mathrm{ABA}$ treatment induced $\mathrm{H}_{2} \mathrm{O}_{2}$ production and stomatal closure, but $\mathrm{FC}$ inhibited the effects of ABA on these two parameters. Treatment with catalase (CAT) and NADPH oxidase inhibitor diphenylene iodonium (DPI) mimicked the effect of FC. These data suggest that inhibition of ABA effect by FC is related to the decrease of $\mathrm{H}_{2} \mathrm{O}_{2}$ levels in guard cells. Furthermore, similar to CAT, FC not only suppressed stomatal closure and $\mathrm{H}_{2} \mathrm{O}_{2}$ levels in guard cells treated with exogenous $\mathrm{H}_{2} \mathrm{O}_{2}$, but also reopened the stomata which had been closed by $A B A$ and reduced the level of $\mathrm{H}_{2} \mathrm{O}_{2}$ that had been produced by $A B A$, indicating that $\mathrm{FC}$ causes $\mathrm{H}_{2} \mathrm{O}_{2}$ removal in guard cells. The butyric acid treatment simulated the effects of $\mathrm{FC}$ on the stomatal aperture and $\mathrm{H}_{2} \mathrm{O}_{2}$ levels in guard cells treated with exogenous $\mathrm{H}_{2} \mathrm{O}_{2}$ and had been closed by $A B A$, and both $\mathrm{FC}$ and butyric acid reduced cytosolic pH in guard cells of stomata treated with $\mathrm{H}_{2} \mathrm{O}_{2}$ and had been closed by $\mathrm{ABA}$, which demonstrate that cytosolic acidification mediates $\mathrm{FC}$-induced $\mathrm{H}_{2} \mathrm{O}_{2}$ removal.
\end{abstract}

Conclusion: These results suggest that FC causes cytosolic acidification in guard cells, then induces $\mathrm{H}_{2} \mathrm{O}_{2}$ removal and reduces $\mathrm{H}_{2} \mathrm{O}_{2}$ levels in guard cells, finally inhibits stomatal closure induced by ABA.

Keywords: Abscisic acid; Cytosolic acidification; Fusicoccin; Guard cell; Hydrogen peroxide

\section{Background}

Abscisic acid (ABA) is a phytohormone that plays vital roles in the control of growth and development and is involved in the response to various environmental stresses. ABA has been demonstrated to affect leaf size, shoot growth, stomatal and lateral root development (Parent et al. 2009; Finkelstein et al. 2002; Arend et al. 2009; Lenoble et al. 2004; de Smet et al. 2003). Moreover, it's generally known ABA as a stress signal in plants. Drought and high salinity resulted in strong increases of plant $A B A$ levels, accompanied by a major change in gene expression and in adaptive physiological responses (Christmann et al.

\footnotetext{
* Correspondence: shexiaoping@snnu.edu.cn

College of Life Sciences, Shaanxi Normal University, 710062 Xi'an, China
}

2007; Rabbani et al. 2003; Zeller et al. 2009). ABA has been shown to induce stomatal closure and reduce the loss of transpirational water from plants under drought conditions (García-Mata and Lamattina 2001; Luan 2002). A large number of ABA signaling intermediates has been identified in guard cells, including cytosolic calcium, protein kinases, cADPR, G proteins and ion channels (Hamilton et al. 2000; Schroeder et al. 2001; Leckie et al. 1998; Wang et al. 2001). Moreover, phospholipid sphingosine-1-phosphate (SIP), phospholipase $\mathrm{C}$ and nitric oxide (NO) have also been suggested to involve in ABA signaling pathways in stomatal closing movement (Hetherington 2001; Ng et al. 2001; Bright et al. 2006; Zhang et al. 2007). 
Fusicoccin (FC), a fungal phytotoxin produced by Fusicoccum amydali, stimulates several physiological and biochemical processes, such as cell elongation, breaking of seed dormancy, ethylene production, stomatal opening and solute transport (Marrè 1979; Malerba et al. 1995). Since several lines of evidence obtained both in vivo and in vitro proved that $\mathrm{FC}$ is a powerful activator of the plasma membrane (PM) $\mathrm{H}^{+}$-ATPase, most of the effects induced by the toxin in the plant tissues have been ascribed to the activation of this transport system (Marrè 1979; Beffagna et al. 1977; Palmgren 1998). It is now widely accepted that FC activates the $\mathrm{H}^{+}$-ATPase by binding to a regulatory protein belonging to the 14-3-3 family, whose association with a specific binding sequence located at the end of the C-terminal autoinhibitory domain of the PM H $\mathrm{H}^{+}$-ATPase releases the autoinhibitory action (Beffagna and Lutzu 2007). FC binding promotes and stabilizes this association, releases the autoinhibitory action and thus induces the activation of $\mathrm{H}^{+}$-ATPase (Olsson et al. 1998; Svennelid et al. 1999; Kinoshita and Shimazaki 2001).

Previous studies demonstrate that ABA induces $\mathrm{H}_{2} \mathrm{O}_{2}$ production and partially blocks both blue light- and FC-dependent activation of $\mathrm{H}^{+}$-ATPases by decreasing in phosphorylation of $\mathrm{H}^{+}$-ATPase via $\mathrm{H}_{2} \mathrm{O}_{2}$ (Schroeder et al. 2001; Zhang et al. 2004; Goh et al. 1996), and cytosolic alkalinization is an early step preceding the production of reactive oxygen species (ROS) in the ABA-triggered signal cascade in guard cells (Suhita et al. 2004; Gonugunta et al. 2008; Islam et al. 2010; Gehring et al. 1997). However, Irving et al. reported that acidification of guard cell cytosol by kinetin, IAA or FC preceded stomatal opening (Irving et al. 1992), $\mathrm{H}^{+}$-ATPase could be activated by FC powerfully (Marrè 1979; Beffagna et al. 1977), and a decrease of endogenous $\mathrm{H}_{2} \mathrm{O}_{2}$ levels were associated with auxins- and cytokinins-induced stomatal opening (Song et al. 2006). These data indicate an opposite action of FC and ABA on cytosolic $\mathrm{pH}, \mathrm{H}^{+}$-ATPase activity and stomatal movement, and it remains unclear whether or not this effect is related to the changes of $\mathrm{H}_{2} \mathrm{O}_{2}$ levels. In the present work, we found that the inhibition of ABA-induced stomatal closure by FC involves a decrease in $\mathrm{H}_{2} \mathrm{O}_{2}$ levels in guard cells of Vicia faba, and the decrease of $\mathrm{H}_{2} \mathrm{O}_{2}$ levels is mediated by cytosolic acidification.

\section{Methods}

\section{Chemicals}

Molecular probes 2',7'-dichlorodihydrofluorescein diacetate $\left(\mathrm{H}_{2} \mathrm{DCF}-\mathrm{DA}\right)$ was obtained from Biotium (Hayward, CA). The fluorescence probes of $2^{\prime}, 7^{\prime}$-bis(2-carboxyethyl)5n-carboxy fluorescein-acetoxy methyl ester (BCECF$\mathrm{AM}$ ), ABA, fusicoccin (FC), catalase (CAT, from bovine liver), diphenylene iodonium (DPI), DMSO, Pluronic F-127,
MES and butyric acid were purchased from Sigma-Aldrich (St Louis, MO). Unless stated otherwise, the remaining chemicals were of the highest analytical grade available from various suppliers of Chinese companies.

\section{Plant materials}

Broad bean (Vicia faba L.) was grown in a controlledenvironment plant growth chamber with a humidity of $80 \%$, a photon flux density of $300 \mu \mathrm{mol} \mathrm{m} \mathrm{m}^{-2} \mathrm{~s}^{-1}$ PAR generated by cool white fluorescent tubes (Philips, New York, NY), and an ambient temperature $25 \pm 2{ }^{\circ} \mathrm{C}$ with a 14-h light and 10-h dark cycle. The epidermis was peeled carefully from the abaxial surface of the youngest, fully expanded leaves of 4-week-old seedlings, and cut into pieces about $5 \mathrm{~mm}$ width and $5 \mathrm{~mm}$ lengths.

\section{Stomatal bioassay}

Stomatal apertures were monitored by the method of McAinsh et al. (McAinsh et al. 1996) with slight modifications. To study the effects of FC, CAT and DPI on stomatal closure caused by ABA, freshly prepared abaxial epidermal strips were incubated in $\mathrm{CO}_{2}$-free $\mathrm{MES} / \mathrm{KCl}$ buffer $\left(10 \mathrm{mM} \mathrm{MES/KOH,} 50 \mathrm{mM} \mathrm{KCl,} 100 \mu \mathrm{M} \mathrm{CaCl}_{2}\right.$, $\mathrm{pH}$ 6.15) with FC, CAT or DPI for $3 \mathrm{~h}$ with ABA under light conditions $\left(300 \mu \mathrm{mol} \mathrm{m} \mathrm{m}^{-2}\right)$ at $25 \pm 2^{\circ} \mathrm{C}$. Final stomatal apertures were recorded with a light microscope and an eyepiece graticule previously calibrated with a stage micrometer. To study the effects of FC, CAT and butyric acid on stomatal closure caused by exogenous $\mathrm{H}_{2} \mathrm{O}_{2}$, epidermal strips were incubated in $\mathrm{MES} / \mathrm{KCl}$ buffer with $\mathrm{H}_{2} \mathrm{O}_{2}$ alone, or containing FC, CAT and different concentrations of butyric acid for $3 \mathrm{~h}$, and then the stomatal apertures were recorded. To study the effects of FC, CAT and butyric acid on stomata that had been closed by $\mathrm{ABA}$, strips were incubated in $\mathrm{MES} / \mathrm{KCl}$ buffer for $3 \mathrm{~h}$ with $\mathrm{ABA}$ and were then treated with fresh buffer alone, or containing FC, CAT and different concentrations of butyric acid for another $1 \mathrm{~h}$, final stomatal apertures were recorded.

To avoid any potential rhythmic effects on stomatal aperture, experiments were always started at the same time of the day. In each treatment, we scored 30 randomly selected apertures per replicate and treatments were repeated three times. The data presented are the means of 90 measurements \pm s.e.

\section{Dyes loading of $\mathrm{H}_{2}$ DCF-DA and BCECF-AM}

$\mathrm{H}_{2} \mathrm{O}_{2}$ content and cytosolic $\mathrm{pH}$ of guard cells were monitored with $\mathrm{H}_{2}$ DCF-DA and BCECF-AM, respectively, as previously described (Irving et al. 1992; Allan and Fluhr 1997) with minor modifications.

The epidermal strips were treated as described for stomatal bioassay section, and were then loaded with $50 \mu \mathrm{M}$ $\mathrm{H}_{2}$ DCF-DA (10 min) or $20 \mu \mathrm{M}$ BCECF-AM (10 min), in 
Tris- $\mathrm{KCl}$ loading buffer (Tris $10 \mathrm{mM}$ and $\mathrm{KCl} 50 \mathrm{mM}$, $\mathrm{pH} 7.2$ ) containing $0.05 \%$ Pluronic F-127 in the dark at $25 \pm 2{ }^{\circ} \mathrm{C}$. In experiment involving time-course monitoring of $\mathrm{H}_{2} \mathrm{O}_{2}$ levels and cytosolic $\mathrm{pH}$ in guard cells, the epidermal strips were treated with $\mathrm{ABA}$ for $3 \mathrm{~h}$ and then with FC for another 10, 20, 30, 40, 50, or 60 min before loading with probes.

\section{Laser-scanning confocal microscopy}

After excess dye was washed off with fresh Tris- $\mathrm{KCl}$ loading buffer in darkness, TCS SP5 laser-scanning confocal microscopy (Leica Lasertechnik Gmbh, Heidelberg, Germany) was used to measure cytosolic $\mathrm{pH}$ or $\mathrm{H}_{2} \mathrm{O}_{2}$ content in guard cells of Vicia faba (excitation $488 \mathrm{~nm}$, emission 505-530 nm, power 15\%, PMT 959, pinhole 0.000036 , zoom $\sim 4$, normal scanning speed, frame $512 \times$ 512 pixels). Images acquired from the confocal microscope were analysed with Leica image software and Photoshop. To enable the comparison of changes in signal intensity, confocal images were taken under identical conditions (in manual setup) for all samples, and in each treatment we measured three epidermal strips, and the treatment was repeated three times. The selected confocal images represented the same results from three replications.

\section{Statistical analysis}

Statistical analyses were performed by using a one-way ANOVA followed by the least significant difference (l.s.d.) test.

\section{Results}

FC inhibits stomatal closure caused by $A B A$ and reduces ABA-induced $\mathrm{H}_{2} \mathrm{O}_{2}$ levels in guard cells

Previous studies have shown that FC, a fungal phytotoxin, causes irreversible stomatal opening (Assmann and Schwartz 1992; de Boer 1997). To gain insights into the effect of FC on ABA-induced stomatal closure, isolated epidermal strips of $V$. faba was incubated in different concentrations of FC with $10 \mu \mathrm{M}$ ABA. As shown in Figure $1 \mathrm{~A}, \mathrm{FC}$ at concentrations of $\geq 0.1 \mu \mathrm{M}$ obviously inhibited ABA-induced stomatal closure, so $0.1 \mu \mathrm{M}$ FC was used in the following experiments.

Widely researches showed that ABA-induced stomatal closure is related to the production of endogenous $\mathrm{H}_{2} \mathrm{O}_{2}$ (Suhita et al. 2004; Pei et al. 2000; Murata et al. 2001). To know if there is a relationship between the inhibition of ABA-induced stomatal closure by FC and the levels of $\mathrm{H}_{2} \mathrm{O}_{2}$ in guard cells, the strips were treated with CAT (a $\mathrm{H}_{2} \mathrm{O}_{2}$ scavenger) and DPI (an inhibitor of $\mathrm{H}_{2} \mathrm{O}_{2}-$ generating enzyme NADPH oxidase), respectively. The results show that CAT significantly inhibited ABA-induced stomatal closure in a dose-dependent manner (Figure 1B), and DPI suppressed ABA-induced stomatal closure partially
(Figure 1C), indicating that $\mathrm{H}_{2} \mathrm{O}_{2}$ is required for ABAinduced stomatal closure and NADPH oxidase contributes to $\mathrm{H}_{2} \mathrm{O}_{2}$ production, which is consistent with the results reported previously (Zhang et al. 2001). The optimal concentration CAT and DPI on stomatal aperture were 100 units $\mathrm{mL}^{-1}$ and $10 \mu \mathrm{M}$, respectively. These results suggest that, probably like CAT and DPI, FC inhibition of ABA-induced stomatal closure via decreasing $\mathrm{H}_{2} \mathrm{O}_{2}$ levels in guard cells.

To further determine whether inhibition of ABAinduced stomatal closure by $\mathrm{FC}$ is accompanied by a decrease of $\mathrm{H}_{2} \mathrm{O}_{2}$ levels in guard cells, epidermal strips were loaded with $\mathrm{H}_{2}$ DCF-DA, a specific probe for intracellular $\mathrm{H}_{2} \mathrm{O}_{2}$ (Allan and Fluhr 1997), to measure $\mathrm{H}_{2} \mathrm{O}_{2}$ levels directly in guard cells. As shown in Figure 2B, ABA induced an intense DCF fluorescence in guard cells, which is consistent with previous reports (Suhita et al. 2004; Pei et al. 2000; Murata et al. 2001). However, ABA-induced DCF fluorescence in guard cells was largely prevented by FC (Figure 2D). Similarly, treatment with CAT or DPI also substantially suppressed ABA-induced DCF fluorescence (Figure 2F,H). These results provide evidence that, like CAT and DPI, FC surely decreases $\mathrm{H}_{2} \mathrm{O}_{2}$ levels induced by $\mathrm{ABA}$ in guard cells.

Both FC and butyric acid suppress exogenous $\mathrm{H}_{2} \mathrm{O}_{2}$-induced stomatal closure and DCF fluorescence in guard cells

Given that FC inhibition of ABA-induced stomatal closure is associated with a decrease of $\mathrm{H}_{2} \mathrm{O}_{2}$ levels in guard cells, we studied the pattern of $\mathrm{H}_{2} \mathrm{O}_{2}$ levels decreasing in response to FC. Epidermal strips were incubated in $\mathrm{MES} / \mathrm{KCl}$ with $\mathrm{H}_{2} \mathrm{O}_{2}$ alone or containing FC, CAT or DPI for $3 \mathrm{~h}$. As shown in Figure 3A, exogenous application of $\mathrm{H}_{2} \mathrm{O}_{2}$ obviously promoted stomatal closure, FC, CAT and DPI alone did not cause any changes of stomatal apertures. However, similar to CAT, FC significantly prevented stomatal closure induced by exogenous $\mathrm{H}_{2} \mathrm{O}_{2}(P<0.05)$. DPI, an inhibitor of $\mathrm{H}_{2} \mathrm{O}_{2}$-generating enzyme $\mathrm{NADPH}$ oxidase, had no obvious effect on exogenous $\mathrm{H}_{2} \mathrm{O}_{2}$ induced stomatal closure (Figure 3A). The results indicate that $\mathrm{FC}$ decreases $\mathrm{H}_{2} \mathrm{O}_{2}$ levels probably via inducing $\mathrm{H}_{2} \mathrm{O}_{2}$ removal but not inhibiting the generation of $\mathrm{H}_{2} \mathrm{O}_{2}$, thereby preventing exogenous $\mathrm{H}_{2} \mathrm{O}_{2}$-induced stomatal closure.

To further clarify whether FC can affect exogenous $\mathrm{H}_{2} \mathrm{O}_{2}$-induced DCF fluorescence, the epidermal strips were treated with $\mathrm{H}_{2} \mathrm{O}_{2}$ in the presence of $\mathrm{FC}$ for $3 \mathrm{~h}$, and then $\mathrm{H}_{2} \mathrm{O}_{2}$ levels were measured. As shown in Figure $3 \mathrm{~B}$, a striking DCF fluorescence in guard cells was observed after treatment with $100 \mu \mathrm{M} \mathrm{H}_{2} \mathrm{O}_{2}$. Compared with the control, there were no changes of DCF fluorescence in guard cells treated with FC alone (Figure 3B). However, $\mathrm{H}_{2} \mathrm{O}_{2}$-induced DCF fluorescence in guard cells was largely prevented by FC (Figure 3B). Similarly, CAT 
Figure $1 \mathrm{FC}$ inhibits ABA-induced stomatal closure. Stomatal apertures were measured under light conditions $\left(300 \mu \mathrm{mol} \mathrm{m}^{-2} \mathrm{~s}^{-1}\right)$ at $25 \pm 2^{\circ} \mathrm{C}$. Values are the means of 90 measurements \pm s.e. from three independent experiments. The asterisks in (A), (B) and (C) indicate that the mean value is significantly different from that of the control at $\mathrm{P}<0.05$ based on Fisher LSD post hoc test, respectively.

also substantially suppressed exogenous $\mathrm{H}_{2} \mathrm{O}_{2}$-induced DCF fluorescence (Figure 3B). DPI had no obvious effect on fluorescence (Figure $3 \mathrm{~B}$ ). These results show that like CAT, FC really induces $\mathrm{H}_{2} \mathrm{O}_{2}$ removal, and consequently reduces $\mathrm{H}_{2} \mathrm{O}_{2}$ level in guard cells treated with exogenous $\mathrm{H}_{2} \mathrm{O}_{2}$.

Previous study demonstrated that FC causes guard cells cytosolic acidification (Irving et al. 1992). These results prompt us to explore whether or not guard cells cytosolic acidification mediates $\mathrm{H}_{2} \mathrm{O}_{2}$ decrease induced by FC. For this purpose, we studied the effects of butyric acid on exogenous $\mathrm{H}_{2} \mathrm{O}_{2}$-induced stomatal closure and $\mathrm{H}_{2} \mathrm{O}_{2}$ levels in guard cells treated with exogenous $\mathrm{H}_{2} \mathrm{O}_{2}$. As shown in Figure 3C, butyric acid at the concentration of $\geq 0.5 \mathrm{mM}$ significantly suppressed exogenous $\mathrm{H}_{2} \mathrm{O}_{2}$-induced stomatal closure $(P<0.05)$ (Figure $\left.3 \mathrm{C}\right)$ and markedly reduced $\mathrm{H}_{2} \mathrm{O}_{2}$ contents in guard cells treated with exogenous $\mathrm{H}_{2} \mathrm{O}_{2}(P<0.05)$ (Figure 3D). The results indicate that cytosolic acidification really promotes the removal of $\mathrm{H}_{2} \mathrm{O}_{2}$ within guard cells, thereby preventing $\mathrm{H}_{2} \mathrm{O}_{2}$-induced stomatal closure.

Both FC and butyric acid reopen the stomata had been closed by ABA and reduce the level of $\mathrm{H}_{2} \mathrm{O}_{2}$ had been generated by ABA in guard cells.

To further ascertain whether or not $\mathrm{FC}$ induces $\mathrm{H}_{2} \mathrm{O}_{2}$ removal, we also compared the effects of FC with CAT on the closed stomata induced by $\mathrm{ABA}$ and the level of $\mathrm{H}_{2} \mathrm{O}_{2}$ generated by ABA. As shown in Figure 4A, both FC and CAT obviously induced the closed stomata caused by ABA to reopen. The results indicate that, similar to CAT, FC induces the removal of $\mathrm{H}_{2} \mathrm{O}_{2}$ having been generated by $\mathrm{ABA}$, thus resulting in stomatal reopening.

The effect of FC on the level of $\mathrm{H}_{2} \mathrm{O}_{2}$ that had been generated by ABA in guard cells was also measured in the present studies. After an incubation of $3 \mathrm{~h}$ in MES/ $\mathrm{KCl}$ buffer in $\mathrm{ABA}$, the strips were treated with fresh $\mathrm{MES} / \mathrm{KCl}$ buffer alone, or containing $\mathrm{FC}$ and CAT for another $1 \mathrm{~h}$, and then were loaded with $\mathrm{H}_{2}$ DCF-DA, washed, and examined by laser scanning confocal microscopy. As shown in Figure 4B, compared with the control, both FC and CAT largely abolished the DCF fluorescence of guard cells. These results suggest that, the treatment of FC induces $\mathrm{H}_{2} \mathrm{O}_{2}$ removal, hence reduces the level of $\mathrm{H}_{2} \mathrm{O}_{2}$ induced by $\mathrm{ABA}$ in guard cells.

To further explore whether or not cytosolic acidification is related to the removal of $\mathrm{H}_{2} \mathrm{O}_{2}$ in guard cells, the 

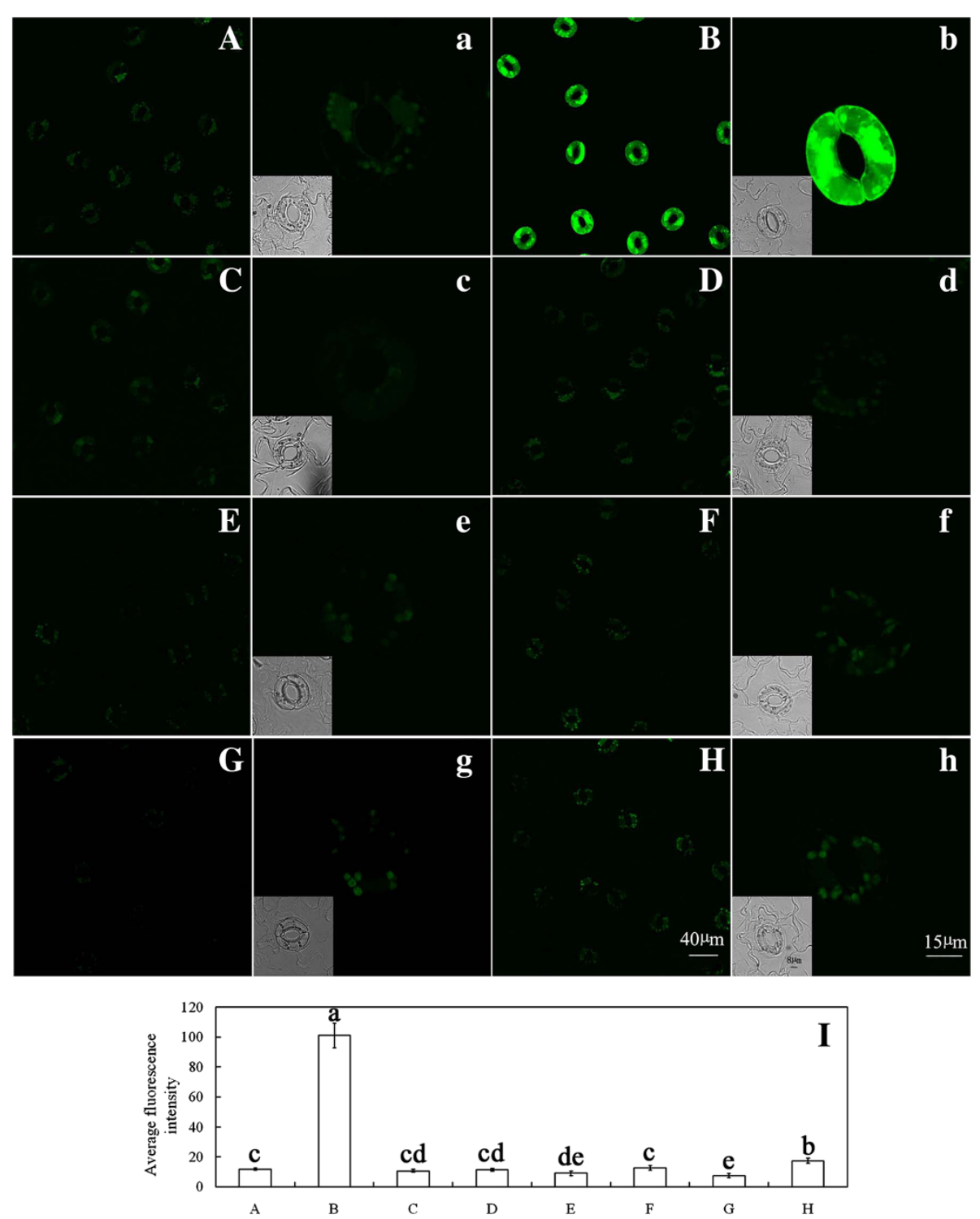

Figure $2 \mathrm{FC}$ reduces $\mathrm{ABA}$-induced $\mathrm{H}_{2} \mathrm{O}_{2}$ level in guard cells. Guard cells of Vicia faba shown in image (A) were treated with $\mathrm{CO}_{2}$-free $\mathrm{MES} / \mathrm{KCl}$ buffer alone for $3 \mathrm{~h}$ under light conditions $\left(300 \mu \mathrm{mol} \mathrm{m} \mathrm{m}^{-2} \mathrm{~s}^{-1}\right)$ at $25^{\circ} \mathrm{C}$. Guard cells shown in image (B) were treated with $10 \mu \mathrm{M} \mathrm{ABA}$, (C) with $0.1 \mu \mathrm{M} \mathrm{FC,} \mathrm{(D)} 0.1 \mu \mathrm{M} \mathrm{FC}+10 \mu \mathrm{M} \mathrm{ABA}$, (E) 100 units $\mathrm{mL}^{-1}$ CAT, (F) 100 units $\mathrm{mL}^{-1}$ CAT +10 $\mu \mathrm{M}$ ABA, (G) $10 \mu \mathrm{M}$ DPI, (H) $10 \mu \mathrm{M}$ DPI +10 $\mu \mathrm{M}$ ABA. (I) The average fluorescence intensity of guard cells in images $(\mathbf{A}-\mathbf{H})$, data are means \pm s.e. Values in (I) with different letters are significantly different at $\mathrm{P}<0.05$ based on Fisher LSD post hoc test. The guard cells shown in image (a-h) are the representative of guard cells shown in image $(\mathbf{A}-\mathbf{H})$. The insets show the bright-field images corresponding to the fluorescence images $(\mathbf{a}-\mathbf{h})$. Scale bars in image $\mathbf{( H )}$ and $(\mathbf{h})$ represent 40 and $15 \mu \mathrm{m}$ for images $(\mathbf{A}-\mathbf{H})$ and $\mathbf{( a - h )}$, respectively. The bar in inset of image (h) represents $8 \mu \mathrm{m}$ for all insets. Each experiment was repeated at least three times, and the selected confocal image represented the same results from approximately nine time measurements.

effects of butyric acid on the stomata had been closed by ABA and the level of $\mathrm{H}_{2} \mathrm{O}_{2}$ had been generated by ABA were measured. Figure 4 shows that, butyric acid at the concentration of $\geq 0.5 \mathrm{mM}$ evidently reopened the stomata had been closed by ABA $(P<0.05)$ (Figure $4 \mathrm{C}$ ), and markedly reduced the level of $\mathrm{H}_{2} \mathrm{O}_{2}$ had been generated by ABA $(P<0.05)$ (Figure $4 \mathrm{D})$. The results provide evidence that cytosolic acidification assuredly induces
$\mathrm{H}_{2} \mathrm{O}_{2}$ removal in guard cells, and thus reopens the stomata had been closed by ABA.

Both $\mathrm{FC}$ and butyric acid reduce cytosolic $\mathrm{pH}$ in guard cells treated with exogenous $\mathrm{H}_{2} \mathrm{O}_{2}$ and stomata had been closed by ABA

To further determine whether or not cytosolic acidification in guard cells mediates FC-induced $\mathrm{H}_{2} \mathrm{O}_{2}$ removal, we measured the effect of $\mathrm{FC}$ on cytosolic $\mathrm{pH}$ in 

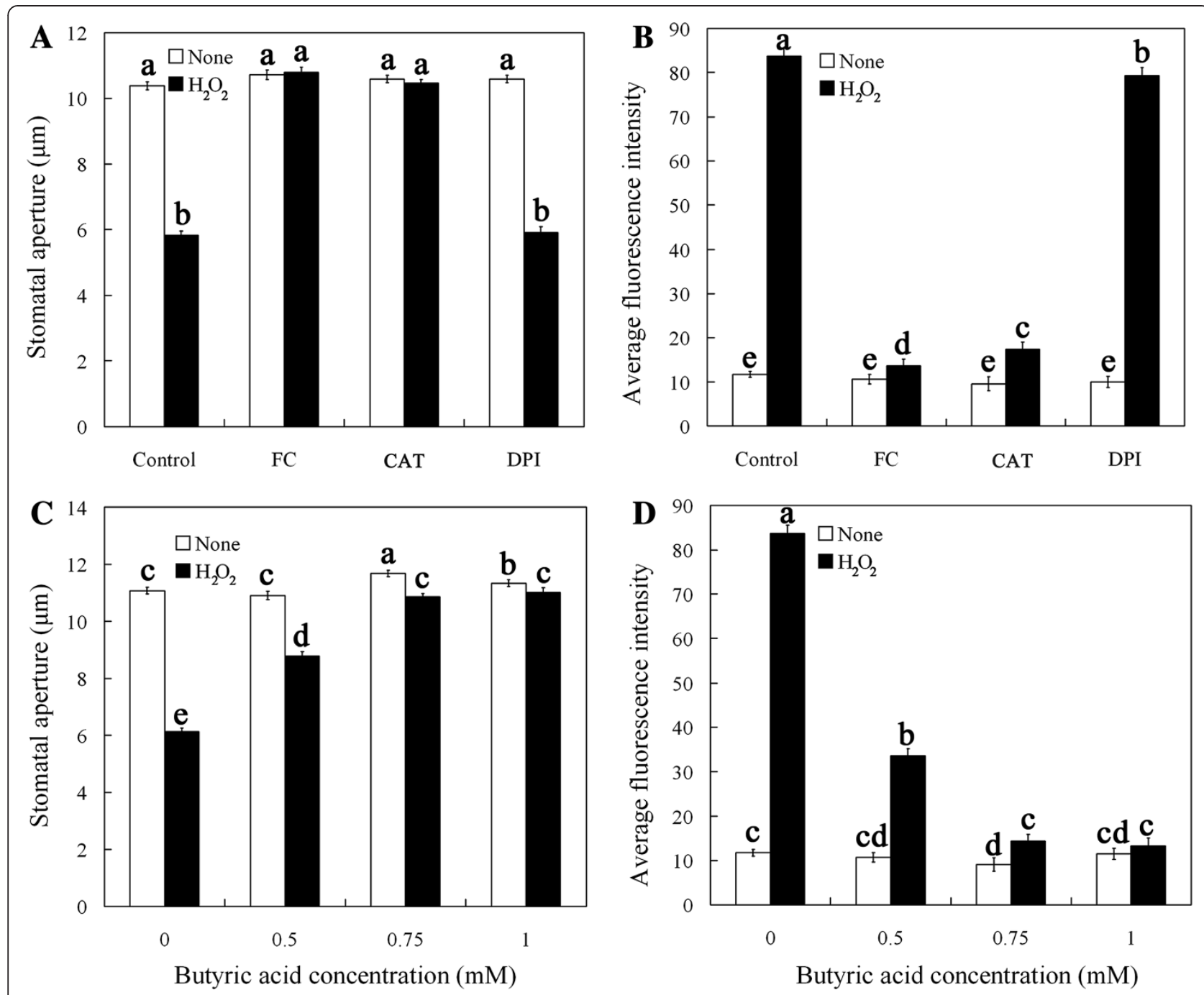

Figure $3 \mathrm{FC}$ and butyric acid suppress exogenous $\mathrm{H}_{2} \mathrm{O}_{2}$-induced stomatal closure $(A, C)$ and reduces $\mathrm{H}_{2} \mathrm{O}_{2}$ levels $(\mathrm{B}, \mathrm{D})$ in guard cells treated with exogenous $\mathrm{H}_{2} \mathrm{O}_{2}$. Isolated epidermal strips were treated with $0.1 \mu \mathrm{M} \mathrm{FC}, 100$ units $\mathrm{mL}^{-1} \mathrm{CAT}, 10 \mu \mathrm{M}$ DPI or different concentration of butyric acid $(0,0.5,0.75,1.0 \mathrm{mM})$ for $3 \mathrm{~h}$ with $100 \mu \mathrm{M} \mathrm{H} \mathrm{O}_{2}$ at $25^{\circ} \mathrm{C}$. Other explanations are the same as in Figures 1 and 2.

guard cells during ABA-induced stomatal closure, and the effects of FC and butyric acid on BCECF-AM fluorescence in guard cells treated with exogenous $\mathrm{H}_{2} \mathrm{O}_{2}$ and guard cells of stomata had been closed by ABA. As shown in Figure 5B, ABA obviously induced an increase of cytosolic $\mathrm{pH}$ in guard cells $(P<0.05)$, and ABAinduced increase of cytosolic $\mathrm{pH}$ was largely prevented by FC $(P<0.05)$ (Figure 5D). Figures 6 and 7 show that, $0.1 \mu \mathrm{M} F C$ and $0.75 \mathrm{mM}$ butyric acid significantly reduced cytosolic $\mathrm{pH}$ in guard cells treated with exogenous $\mathrm{H}_{2} \mathrm{O}_{2}$ and guard cells of stomata had been closed by ABA. The results confirm that FC surely causes cytosolic acidification, which is consistent with previous result (Irving et al. 1992). Together with the result that ABAand exogenous $\mathrm{H}_{2} \mathrm{O}_{2}$ - induced increase of $\mathrm{H}_{2} \mathrm{O}_{2}$ level was evidently reduced by FC and butyric acid (Figures 2D and $3 \mathrm{~B}$ ), the data from Figure 5, 6 and 7 suggest that FC-induced the decrease of $\mathrm{H}_{2} \mathrm{O}_{2}$ level is associated with guard cells cytosolic acidification during $\mathrm{ABA}$-induced stomatal closure.

Furthermore, we determined the kinetics of FC treatment on $\mathrm{H}_{2} \mathrm{O}_{2}$ levels or $\mathrm{pH}$ changes in guard cells of stomata had been closed by ABA. Treatment of ABA for $3 \mathrm{~h}$ caused a marked increase in both $\mathrm{H}_{2} \mathrm{O}_{2}$ levels and $\mathrm{pH}$ of guard cells (Figures $2 \mathrm{~B}$ and $5 \mathrm{~B}$ ). When the strips were then treated with FC, the BCECF-AM fluorescence of guard cells decreased sharply after $10 \mathrm{~min}$ and declined to 54\% (Figure 8A). Then BCECF-AM fluorescence dropped continually and reached minimum by 60 min (Figure 8A). In contrast, $\mathrm{H}_{2} \mathrm{O}_{2}$ levels of guard cells on exposure to $\mathrm{FC}$ were drop to $75 \%$ after $10 \mathrm{~min}$ (Figure $8 \mathrm{~B}$ ), then felled continually and reached minimum 


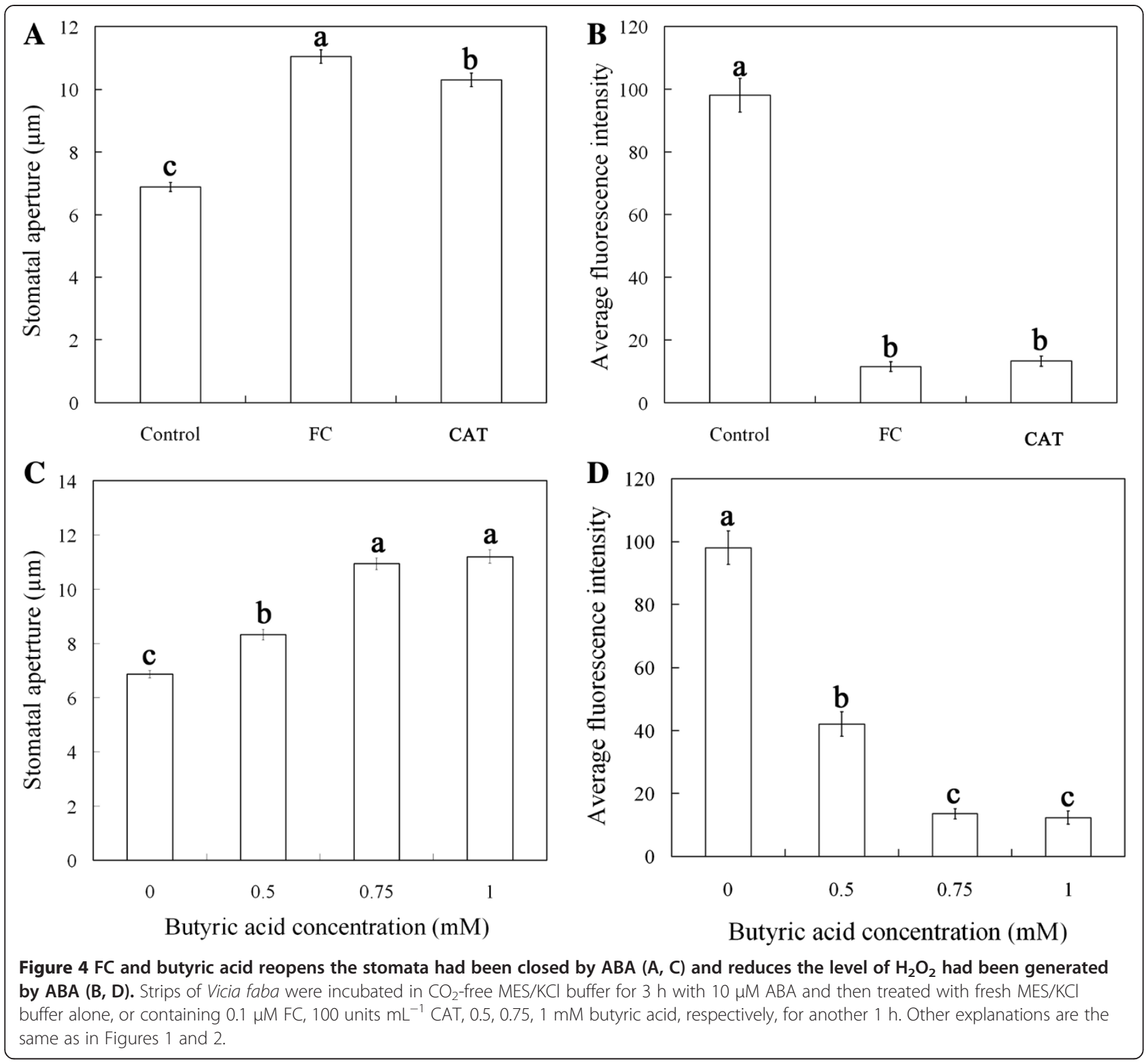

by 60 min (Figure $8 \mathrm{~B}$ ). Thus, the drop in $\mathrm{pH}$ of guard cells appeared to occur earlier to that of $\mathrm{H}_{2} \mathrm{O}_{2}$ levels decrease (Figure 8), confirming that cytosolic acidification precedes $\mathrm{H}_{2} \mathrm{O}_{2}$ removal during inhibition of ABA-induced stomatal closure by fusicoccin.

\section{Discussion}

Guard cells control transpiration in plants and regulate gas exchange in leaves by opening and closing stomatal pores. Stomatal opening is induced by many abiotic and biotic factors, including light, indoleacetic acid (IAA), FC, cytokinins, low $\mathrm{CO}_{2}$ levels and high humidity (Mansfield and Atkinson 1990; Jewer and Incoll 1980; Pemadasa 1982; Braunsgaard et al. 1998), and stomatal closure can be promoted by dark, osmotic stress, high $\mathrm{CO}_{2}$ concentrations, decreased humidity and ABA (Schroeder et al. 2001; Kearns and Assmann 1993). Previous studies demonstrated that cytosolic alkalinization of guard cell precedes ROS production and is required for ABA- and MJ-induced stomatal closure (Suhita et al. 2004; Islam et al. 2010; Gehring et al. 1997; Gonugunta et al. 2009). FC, IAA and kinetin decreased the cytosolic $\mathrm{pH}$ and promoted stomatal opening (Irving et al. 1992), and a decrease of endogenous $\mathrm{H}_{2} \mathrm{O}_{2}$ levels were associated with auxins- and cytokininsinduced stomatal opening (Song et al. 2006). These results suggested that cytosolic $\mathrm{pH}$ was an important factor in the regulation of $\mathrm{H}_{2} \mathrm{O}_{2}$ levels and stomatal movement. However, until recently, little was known whether the inhibition of ABA-induced stomatal closure by FC is related to the change of cytosolic $\mathrm{pH}$ and $\mathrm{H}_{2} \mathrm{O}_{2}$ levels in guard cells. 

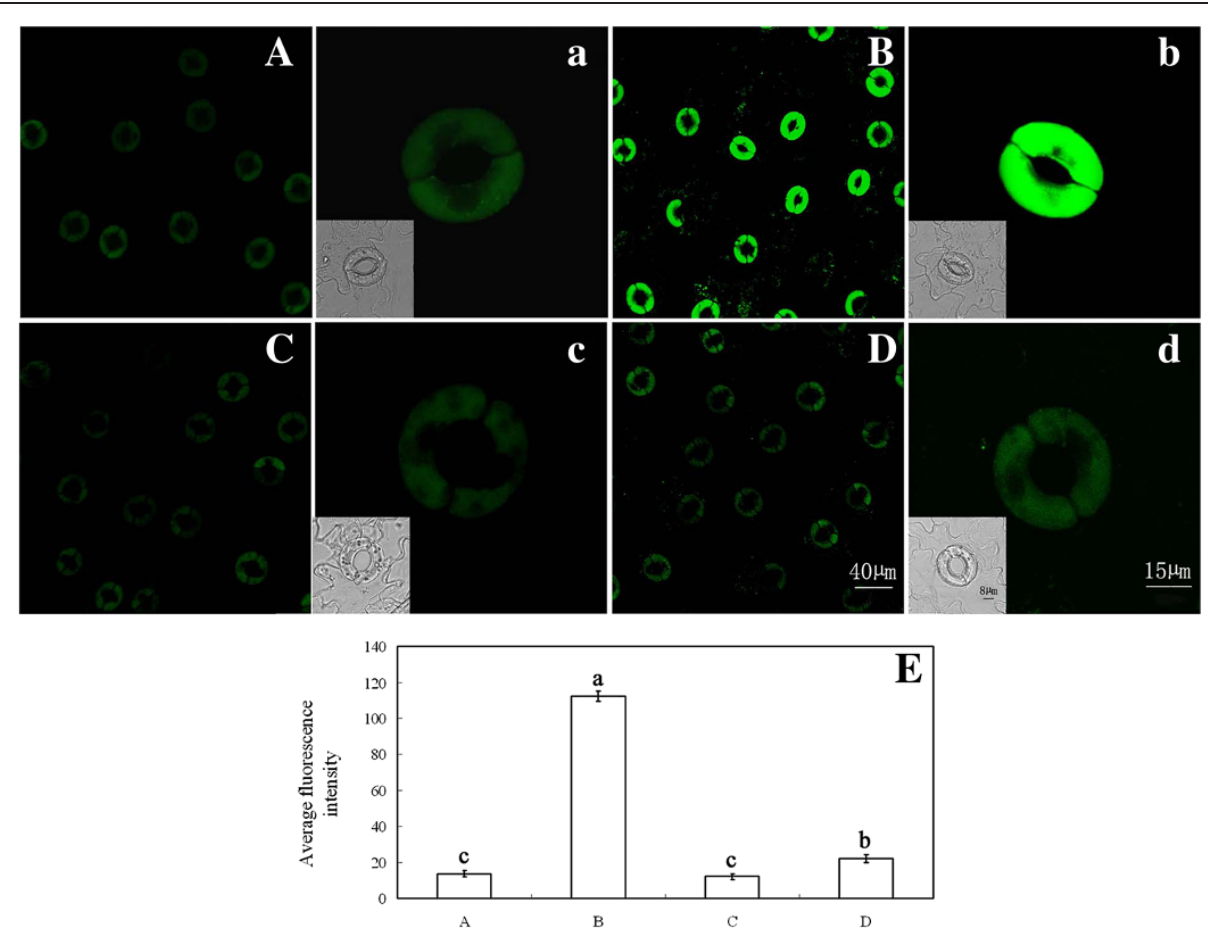

Figure 5 FC reduces cytosolic $\mathbf{p H}$ in guard cells during ABA-induced stoamatal closure. Guard cells of Vicia faba shown in image (A) were treated with MES/KCl buffer alone, (B) with $10 \mu \mathrm{M} \mathrm{ABA}$, (C) $0.1 \mu \mathrm{M} \mathrm{FC,} \mathrm{(D)} 0.1 \mu \mathrm{M} \mathrm{FC}+10 \mu \mathrm{M} \mathrm{ABA}$ for $3 \mathrm{~h}$ at $25^{\circ} \mathrm{C}$. The guard cells shown in image (a-d) are the representative of guard cells shown in image (A-D). (E) The average fluorescence intensity of guard cells in images (A-D), data are means \pm s.e. Values in $(\mathbf{D})$ with different letters are significantly different at $P<0.05$ based on Fisher LSD post hoc test. Other explanations are the same as in Figure 2.

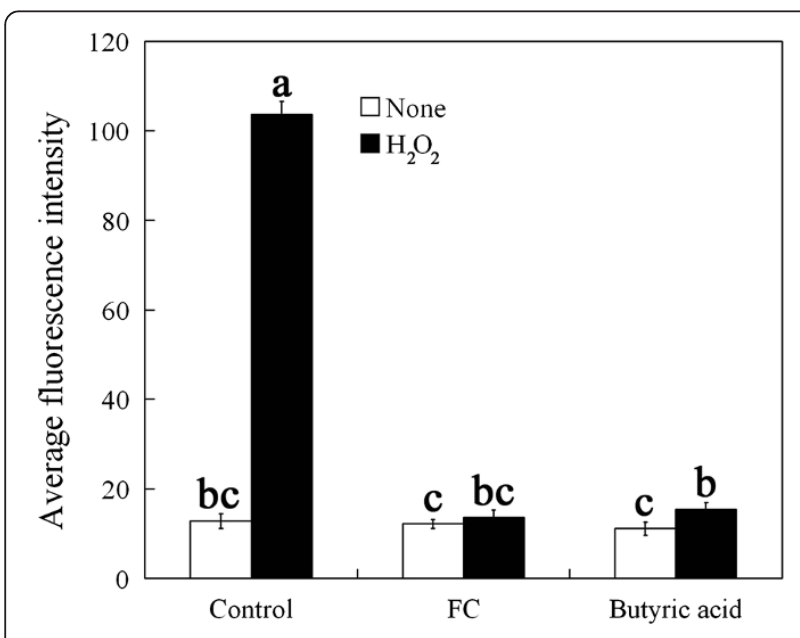

Figure $6 \mathrm{FC}$ and butyric acid reduces cytosol $\mathrm{pH}$ in guard cells treated with exogenous $\mathrm{H}_{2} \mathrm{O}_{2}$. Isolated epidermal strips were incubated in $\mathrm{MES} / \mathrm{KCl}$ buffer alone, or containing $0.1 \mu \mathrm{M} \mathrm{FC}$, $0.75 \mathrm{mM}$ butyric acid, $100 \mu \mathrm{M} \mathrm{H}_{2} \mathrm{O}_{2}, 100 \mu \mathrm{M} \mathrm{H}_{2} \mathrm{O}_{2}+0.1 \mu \mathrm{M} \mathrm{FC}$, $100 \mu \mathrm{M} \mathrm{H}_{2} \mathrm{O}_{2}+0.75 \mathrm{mM}$ butyric acid for $3 \mathrm{~h}$ at $25^{\circ} \mathrm{C}$. Other explanations are the same as in Figure 2 .

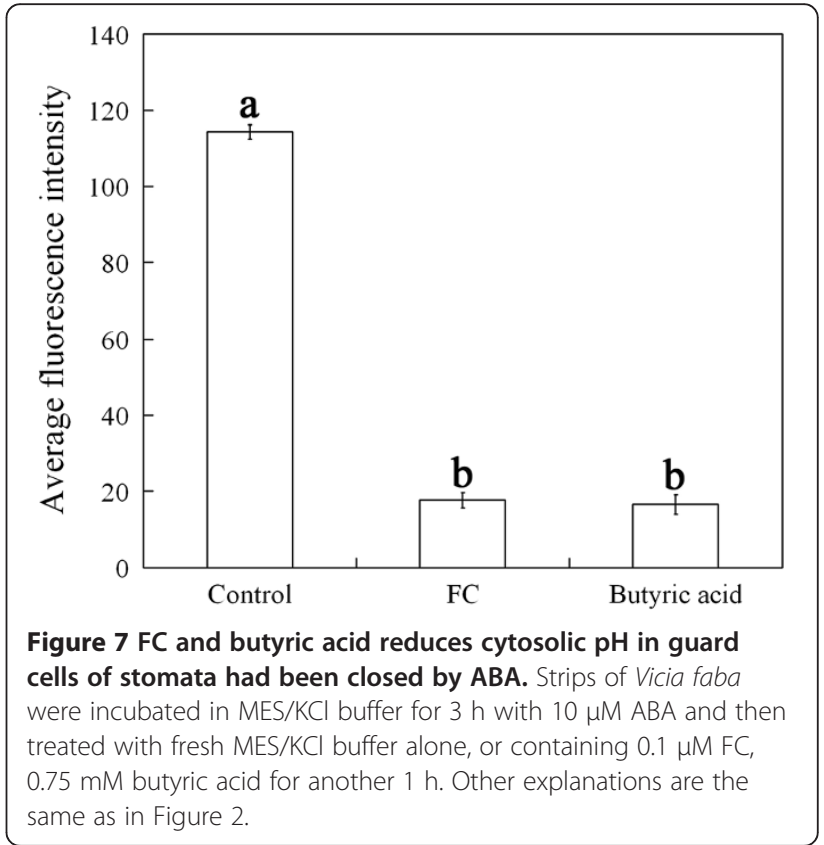



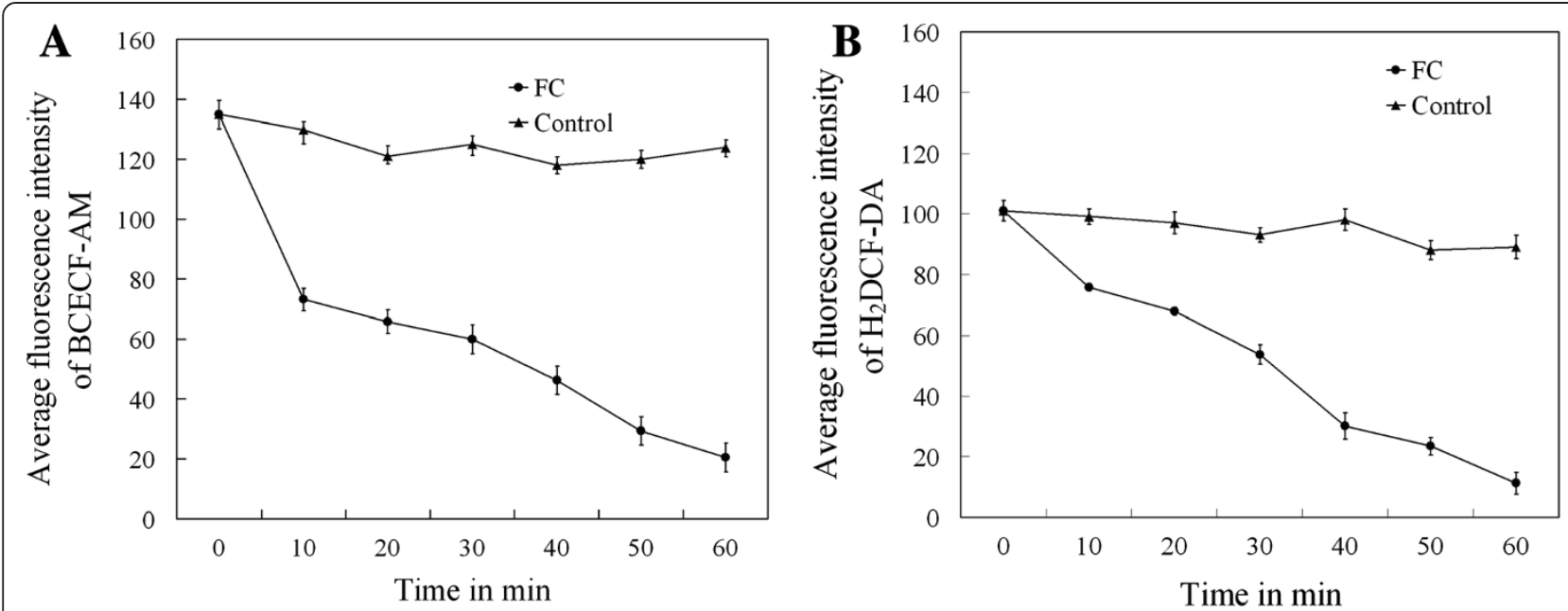

Figure 8 Kinetics of decrease in cytosolic $\mathrm{pH}(\mathrm{A})$ or $\mathrm{H}_{2} \mathrm{O}_{2}$ levels $(\mathrm{B})$ in guard cells of stomata had been closed by $A B A$ in response to $0.1 \mu \mathrm{M}$ FC. Epidermal strips were treated with $10 \mu \mathrm{M}$ ABA for $3 \mathrm{~h}$, and then incubated in $0.1 \mu \mathrm{M}$ FC for 10-60 min. Other explanations are the same as in Figure 2.

The results of the present studies demonstrate that similar to CAT and DPI, FC significantly prevented stomatal closure induced by ABA (Figure 1) and largely reduced $\mathrm{H}_{2} \mathrm{O}_{2}$ levels in guard cells induced by ABA (Figure 2). The results suggest that the inhibition of ABA-induced stomatal closure by $\mathrm{FC}$ is associated with a decrease of $\mathrm{H}_{2} \mathrm{O}_{2}$ levels in guard cells.

Previous reports demonstrated that FC stimulates production of $\mathrm{H}_{2} \mathrm{O}_{2}$ in cultured sycamore and Arabidopsis thaliana cells (Beffagna and Lutzu 2007; Malerba et al. 2003). However, FC was also reported to block cryptogeininduced $\mathrm{H}_{2} \mathrm{O}_{2}$ production of tobacco cells (Simon-Plas et al. 1997). The results of the present study show that the inhibition of ABA-induced stomatal closure by FC is associated with a decrease of $\mathrm{H}_{2} \mathrm{O}_{2}$ levels in stomatal guard cells. The question arises of how FC reduces $\mathrm{H}_{2} \mathrm{O}_{2}$ levels in guard cells. Our results show that FC suppressed exogenous $\mathrm{H}_{2} \mathrm{O}_{2}$-induced stomatal closure and $\mathrm{H}_{2} \mathrm{O}_{2}$ levels in guard cells treated with exogenous $\mathrm{H}_{2} \mathrm{O}_{2}$ (Figure 3A,B), and also reopened the closed stomata by ABA and abolished $\mathrm{H}_{2} \mathrm{O}_{2}$ that had been generated by ABA (Figure 4A,B). The above-mentioned effects of FC are similar to those of CAT (Figures 3A,B, and 4A,B), a scavenger of $\mathrm{H}_{2} \mathrm{O}_{2}$. These results prove that the treatment with $\mathrm{FC}$ induces the removal of $\mathrm{H}_{2} \mathrm{O}_{2}$ within guard cells, thereby prevents stomatal closure induced by exogenous $\mathrm{H}_{2} \mathrm{O}_{2}$, and causes the reopening of the closed stomata by ABA. Together with the facts that FC inhibits stomatal closure induced by ABA (Figure 1A) and reduces $\mathrm{H}_{2} \mathrm{O}_{2}$ levels in guard cells caused by ABA (Figure 2D), we conclude that FC probably initiates an unidentified mechanism, which can reduce $\mathrm{H}_{2} \mathrm{O}_{2}$ levels in guard cells via inducing $\mathrm{H}_{2} \mathrm{O}_{2}$ removal, eventually preventing stomatal closure induced by ABA.
Cytosolic $\mathrm{pH}$ is an important factor in the regulation of stomatal movement (Suhita et al. 2004; Gonugunta et al. 2008; Irving et al. 1992; Blatt 2000; Zhang et al. 2001). Cytosolic alkalinization is a major step in the ABAtriggered signal cascade in guard cells leading to stomatal closure (Irving et al. 1992; Blatt 2000), and further investigation found that cytosolic alkalinization preceded the production of ROS and NO during ABA induced stomatal closure (Suhita et al. 2004; Gonugunta et al. 2008, 2009). In contrast, FC, IAA or a weak acid butyrate, decreased the cytosolic $\mathrm{pH}$ and promoted stomatal opening (Irving et al. 1992), and auxins also reduce $\mathrm{H}_{2} \mathrm{O}_{2}$ levels (Song et al. 2006). These results prompted us to investigate the interaction of $\mathrm{pH}$ and $\mathrm{H}_{2} \mathrm{O}_{2}$ levels in FC-inhibited stomatal closure. In this study, we provide evidence that, similar to butyric acid, FC not only reduced cytosolic pH caused by ABA in guard cells (Figures 5 and 7) but also induced $\mathrm{H}_{2} \mathrm{O}_{2}$ removal (Figures 2 and 4), which suggests that cytosolic acidification in guard cells mediates $\mathrm{H}_{2} \mathrm{O}_{2}$ removal induced by FC. Real-time monitoring with the help of fluorescent dyes BCECF-AM and $\mathrm{H}_{2}$ DCF-DA revealed that $\mathrm{FC}$-induced decrease of cytosolic $\mathrm{pH}$ faster than that of $\mathrm{H}_{2} \mathrm{O}_{2}$ levels and confirmed that acidification of guard cell could be upstream of $\mathrm{H}_{2} \mathrm{O}_{2}$ during inhibition of ABA-induced stomatal closure by FC (Figure 8). Combined with the fact that $\mathrm{FC}$ reduces cytosolic $\mathrm{pH}$ (Figure 5D) and $\mathrm{H}_{2} \mathrm{O}_{2}$ levels (Figure 2D) in guard cells induced by $\mathrm{ABA}$, we conclude that $\mathrm{FC}$ induces $\mathrm{H}_{2} \mathrm{O}_{2}$ removal via reducing cytosol $\mathrm{pH}$, hence lessens $\mathrm{H}_{2} \mathrm{O}_{2}$ levels in guard cells during ABA-induced stomatal closure. It is an intriguing problem about how FC-induced cytosolic acidification causes $\mathrm{H}_{2} \mathrm{O}_{2}$ removal, and we suppose that some $\mathrm{H}_{2} \mathrm{O}_{2}$-scavenging mechanism might be activated, including change of ASA redox state, catalase or ascorbate 
peroxidase activities (Beffagna and Lutzu 2007; Chen and Gallie 2004).

\section{Conclusions}

In summary, these data suggest that $\mathrm{FC}$ induces $\mathrm{H}_{2} \mathrm{O}_{2}$ removal and reduces $\mathrm{H}_{2} \mathrm{O}_{2}$ level via reducing cytosol $\mathrm{pH}$ in guard cells, thus inhibiting ABA-induced stomatal closure.

\section{Abbreviations}

ABA: Abscisic acid; CAT: Catalase; BCECF-AM: 2',7'-bis(2-carboxyethyl)-5(6)carboxy fluorescein-acetoxy methyl ester; DMSO: Dimethyl sulfoxide; DPI: Diphenylene iodonium; FC: Fusicoccin; H2DCF-DA: 2', 7'dichlorodihydrofluorescein diacetate; $\mathrm{H}_{2} \mathrm{O}_{2}$ : Hydrogen peroxide; MES: 2-(N-morpholino)ethanesulfonic acid.

\section{Competing interests}

The authors declare that they have no competing interests.

\section{Authors' contributions}

HAX performed and designed the experiments partly and drafted the manuscript. SXP supervised the study and refined the text with respect to language and the literature citations. ZJL and ZYY performed the experiment partly. All authors read and approved the final manuscript.

\section{Acknowledgments}

This work was financially supported by National Natural Science Foundation of China (31000130) and Opening Foundation of Key Laboratory of Resource Biology and Biotechnology in Western China (Northwest University), Ministry of Education (zs12006)

Received: 23 April 2012 Accepted: 6 September 2013 Published: 17 March 2014

\section{References}

Allan AC, Fluhr R (1997) Two distinct sources of elicited reactive oxygen species in tobacco epidermal cells. Plant Cell 9:1559-1572

Arend $M$, Schnitzler J, Ehlting B, Hänsch R, Lange T, Rennenberg H, Himmelbach A, Grill E, Fromm J (2009) Expression of the Arabidopsis mutant ABl1 gene alters abscisic acid sensitivity, stomatal development, and growth morphology in gray poplars. Plant Physiol 151:2110-2119

Assmann SM, Schwartz A (1992) Synergistic effect of light and fusicoccin on stomatal opening. Plant Physiol 98:1349-1355

Beffagna N, Lutzu I (2007) Inhibition of catalase activity as an early response of Arabidopsis thaliana cultured cells to the phytotoxin fusicoccin. J Exp Bot 58:4183-4194

Beffagna N, Cocucci S, Marrè E (1977) Stimulating effect of fusicoccin on $\mathrm{K}^{+}$-activated ATPase in plasmalemma preparations from higher plant tissues. Plant Sci Lett 8:91-98

Blatt MR (2000) Cellular signaling and volume control in stomatal movements in plants. Annu Rev Cell Dev Biol 16:221-241

Braunsgaard L, Fuglsang AT, Jahn T, Korthout HAAJ, de Boer AH, Palmgren MG (1998) The 14-3-3 proteins associate with plant plasma membrane $\mathrm{H}^{+}$-ATPase to generate a fusicoccin binding complex and a fusicoccin responsive system. Plant J 13:661-671

Bright J, Desikan R, Hancock JT, Weir IS, Neill SJ (2006) ABA-induced NO generation and stomatal closure in Arabidopsis are dependent on $\mathrm{H}_{2} \mathrm{O}_{2}$ synthesis. Plant 45:113-122

Chen Z, Gallie DR (2004) The ascorbic acid redox state controls guard cell signaling and stomatal movement. Plant Cell 16:1143-1162

Christmann A, Weiler EW, Steudle E, Grill E (2007) A hydraulic signal in root-toshoot signalling of water shortage. Plant J 52:167-174

de Boer AH (1997) Fusicoccin-A key to multiple 14-3-3 locks? Trends Plant Sci 2:60-66

de Smet I, Signora L, Beeckman T, Inzé D, Foyer CH, Zhang H (2003) An abscisic acid-sensitive checkpoint in lateral root development of Arabidopsis. Plant 33:543-555

Finkelstein RR, Gampala SSL, CD R (2002) Abscisic acid signaling in seeds and seedlings. Plant Cell 14(Suppl):S15-S45
García-Mata C, Lamattina L (2001) Nitric oxide induces stomatal closure and enhances the adaptive plant responses against drought stress. Plant Physiol 126:1196-1204

Gehring CA, Irving HR, McConchie R, Parish RW (1997) Jasmonates induce intracellular alkalization and closure of Paphiopedilum guard cell. Ann Bot 80:485-489

Goh CH, Kinoshita T, Oku T, Shimazaki K (1996) Inhibition of blue light-dependent $\mathrm{H}^{+}$pumping by abscisic acid in Vicia guard-cell protoplasts. Plant Physiol 111:433-440

Gonugunta VK, Srivastava N, Puli MR, Raghavendra AS (2008) Nitric oxide production occurs after cytosolic alkalinization during stomatal closure induced by abscisic acid. Plant Cell Environ 31:1717-1724

Gonugunta VK, Srivastava N, Raghavendra AS (2009) Cytosolic alkalinization is a common and early messenger preceding the production of ROS and NO during stomatal closure by variable signals, including abscisic acid, methyl jasmonate and chitosan. Plant Signal Behav 4:561-564

Hamilton DW, Hills A, Kohler B, Blatt MR (2000) Ca ${ }^{2+}$ channels at the plasma membrane of stomatal guard cells are activated by hyperpolarization and abscisic acid. Proc Natl Acad Sci USA 97:4967-4972

Hetherington AM (2001) Guard cell signaling. Cell 107:711-714

Irving HR, Gehring CA, Parish RW (1992) Changes in cytosolic pH and calcium of guard cells precede stomatal movements. Proc Natl Acad Sci USA 89:1790-1794

Islam MM, Hossain MA, Jannat R, Munemasa S, Nakamura Y, Mori IC, Murata Y (2010) Cytosolic alkalization and cytosolic calcium oscillation in Arabidopsis guard cells response to ABA and MeJA. Plant Cell Physiol 51:1721-1730

Jewer PC, Incoll LD (1980) Promotion of stomatal opening in the grass anthephora pubescens nees by arrange of natural and synthetic cytokinins. Planta 150:218-221

Kearns EV, Assmann SM (1993) The guard cell-environmental connection. Plant Physiol 102:711-715

Kinoshita T, Shimazaki K (2001) Analysis of the phosphorylation level in guard cell plasma membrane $\mathrm{H}^{+}$-ATPase in response to fusicoccin. Plant Cell Physiol 42:424-432

Leckie CP, McAinsh MR, Allen GJ, Sanders D, Hetherington AM (1998) Abscisic acid-induced stomatal closure mediated by cyclicADP-ribose. Proc Natl Acad Sci USA 95:15837-15842

Svennelid F, Olsson A, Piotrowski M, Rosenquist M, Ottman C, Larsson C, Oecking C, Sommarin M (1999) Phosphorylation of Thr-948 at the $C$ terminus of the plasma membrane $\mathrm{H}^{+}$-ATPase creates a binding site for the regulatory 14-3-3 protein. The Plant Cell 11:2379-2392

Wang XQ, Ullah H, Jones AM, Assmann SM (2001) G protein regulation of ion channels and abscisic acid signaling in Arabidopsis guard cells. Science 292:2070-2072

Zeller G, Henz SR, Widmer CK, Sachsenberg T, Rätsch G, Weigel D, Laubinger S (2009) Stress-induced changes in the Arabidopsis thaliana transcriptome analyzed using whole-genome tiling arrays. The Plant Journal 58:1068-1082

Zhang X, Takemiya A, Kinoshita T, Shimazaki K (2007) Nitric oxide inhibits blue light-specific stomatal opening via abscisic acid signaling pathways in Vicia guard cells. Plant and Cell Physiology 48:715-723

Zhang X, Wang HB, Takemiya A, Song CP, Kinoshita T, Shimazaki KI (2004) Inhibition of blue light-dependent $\mathrm{H}^{+}$pumping by abscisic acid through hydrogen peroxide-induced dephosphorylation of the plasma membrane $\mathrm{H}^{+}$-ATPase in guard cell protoplasts. Plant Physiology 136:4150-4158

Lenoble ME, Spollen WG, Sharp RE (2004) Maintenance of shoot growth by endogenous ABA: genetic assessment of the involvement of ethylene suppression. J Exp Bot 55:237-245

Luan S (2002) Signaling drought in guard cells. Plant Cell Environ 25:229-237

Malerba M, Crosti P, Bianchetti R (1995) Regulation of 1-aminocyclopropane-1carboxylic acid oxidase by the plasmalemma proton pump in Acer pseudoplatanus L. cultured cells. J Plant Physiol 145:711-716

Malerba M, Crosti P. Cerana R, Bianchetti R (2003) Fusicoccin stimulates the production of $\mathrm{H}_{2} \mathrm{O}_{2}$ in sycamore cell cultures and induces alternative respiration and cytochrome c leakage from mitochondria. Physiol Plant 119:480-488

Mansfield TA, Atkinson CJ (1990) Stomatal behaviour in water stressed plants. In: Alscher RG, Cumming JR (eds) Stress Responses in Plants: Adaptation and Acclimation Mechanisms. Academic, New York, pp 241-264

Marrè E (1979) Fusicoccin: a tool in plant physiology. Annu Rev Plant Physiol 30:273-288

McAinsh MR, Clayton H, Mansfield TA, Hetherington AM (1996) Changes in stomatal behavior and guard cell cytosolic free calcium in response to oxidative stress. Plant Physiol 111:1031-1042 
Murata Y, Pei ZM, Mori IC, Schroeder J (2001) Abscisic acid activation of plasma membrane $\mathrm{Ca}^{2+}$-channels in guard cells requires cytosolic $\mathrm{NAD}(\mathrm{P}) \mathrm{H}$ and is differentially disrupted upstream and downstream of reactive oxygen species production in abil-1 and abi2-1 protein phosphatase 2C mutants. Plant Cell 13:2513-2523

Ng CKY, Carr K, McAinsh MR, Powell B, Hetherington AM (2001) Drought-induced guard cell signal transduction involves sphingosine-1-phosphate. Nature 410:596-599

Olsson A, Svennelid F, Ek B, Sommarin M, Larsson C (1998) A phosphothreonine residue at the $\mathrm{C}$-terminal end of the plasma membrane $\mathrm{H}^{+}$-ATPase is protected by fusicoccin-induced 14-3-3 binding. Plant Physiol 118:551-555

Palmgren MG (1998) Proton gradients and plant cell growth: role of the plasma membrane $\mathrm{H}^{+}$-ATPase. Adv Bot Res 28:1-70

Parent B, Hachez C, Redondo E, Simonneau T, Chaumont F, Tardieu F (2009) Drought and abscisic acid effects on aquaporin content translate into changes in hydraulic conductivity and leaf growth rate: a trans-scale approach. Plant Physiol 149:2000-2012

Pei ZM, Murata Y, Benning G, Thomine S, Klusener B, Allen GJ, Grill E, Schroeder $J L$ (2000) Calcium channels activated by hydrogen peroxide mediate abscisic acid signaling in guard cells. Nature 406:731-734

Pemadasa MA (1982) Differential abaxial and adaxial stomatal responses to indole-3-acetic acid in Commelina communis L. New Phytol 90:209-219

Rabbani MA, Maruyama K, Abe H, Khan MA, Katsura K, Ito Y, Yoshiwara K, Seki M, Shinozaki K, Yamaguchi-Shinozaki K (2003) Monitoring expression profiles of rice genes under cold, drought, and high-salinity stresses and abscisic acid application using CDNA microarray and RNA gel-blot analyses. Plant Physiol 133:1755-1767

Schroeder Jl, Allen GJ, Hugouvieux V, Kwak JM, Waner D (2001) Guard cell signal transduction. Annu Rev Plant Physiol Plant Mol Biol 52:627-658

Simon-Plas F, Rustérucci C, Milat ML, Humbert C, Montillet JL, Blein JP (1997) Active oxygen species production in tobacco cells elicited by cryptogein. Plant Cell Environ 20:1573-1579

Song XG, She XP, He JM, Huang C, Song TS (2006) Cytokinin- and auxin-induced stomatal opening involves a decrease in levels of hydrogen peroxide in guard cells of Vicia faba. Funct Plant Biol 33:573-583

Suhita D, Raghavendra AS, Kwak JM, Vavasseur A (2004) Cytoplasmic alkalization precedes reactive oxygen species production during methyl jasmonate- and abscisic acid-induced stomatal closure. Plant Physiol 134:1536-1545

Zhang X, Zhang L, Dong FC, Gao JF, Galbraith DW, Song CP (2001) Hydrogen peroxide is involved in abscisic acid-induced stomatal closure in Vicia faba. Plant Physiol 126:1438-1448

doi:10.1186/1999-3110-55-33

Cite this article as: Huang et al:: Inhibition of ABA-induced stomatal closure by fusicoccin is associated with cytosolic acidification-mediated hydrogen peroxide removal. Botanical Studies 2014 55:33.

\section{Submit your manuscript to a SpringerOpen ${ }^{\circ}$ journal and benefit from:}

- Convenient online submission

- Rigorous peer review

- Immediate publication on acceptance

- Open access: articles freely available online

- High visibility within the field

- Retaining the copyright to your article

Submit your next manuscript at $\gg$ springeropen.com 